\title{
EVALUATION OF THE SUSCEPTIBILITY OF SEVERAL PLUM (PRUNUS DOMESTICA L.) CULTIVARS TO PLUM POX VIRUS (PPV) INFECTION IN THE FIELD. SHARKA-LIKE SYMPTOMS OBSERVED ON 'JOJO' FRUIT ARE NOT RELATED TO PPV
}

\author{
Short communication \\ Tadeusz MALINOWSKI*, Elżbieta ROZPARA, Zygmunt S. GRZYB \\ Research Institute of Horticulture \\ Konstytucji 3 Maja 1/3, 96-100 Skierniewice, Poland \\ Received: February 6, 2013; Accepted: June 26, 2013
}

\begin{abstract}
Susceptibility of plum cultivars: 'Katinka', 'Jubileum', 'Diana', 'Valjevka', 'Żółta Afaska', 'Elena', 'Jojo', 'President', 'Vision', and 'Węgierka Zwykła' (Pozegaca type, included as reference, highly susceptible cultivar) to aphid-vectored Plum pox virus (strain D), was evaluated. The trees were grown for 7-8 years in the field characterized with high infection pressure. 'Katinka' and 'President' showed susceptibility even higher than 'Węgierka Zwykła'. 'Vision' and 'Valjevka' showed relatively low susceptibility with less than $30 \%$ of trees becoming infected. All 'Jojo' trees remained free from ELISA-detectable amounts of PPV, although a high percentage of the fruit of this cultivar showed sharka-like symptoms on stones and fruit flesh. The reason for that phenomenon is not known.
\end{abstract}

Key words: plum, sharka, fruit tree protection, hypersensitivity

\section{INTRODUCTION}

Sharka or plum pox, the disease caused by Plum pox virus (PPV), is a serious threat to plum, peach and apricot orchards (Cambra et al. 2006). PPV is transmitted in the field by aphids in a nonpersistent way (Krczal and Kunze 1976). "Nonpersistent" actually means that as short as $30 \mathrm{sec}-$ onds acquisition feeding of an aphid on the infected plant followed by a very short probing feeding (within less than 2-3 hours from acquisition) on the healthy one, may result in transmitting the virus and spreading the disease (Moreno et al. 2009). The most effective and environment friendly way to control the disease is to use immune or highly resistant cultivars for new plantations, if such cultivars are available and show other positive characteristics. Breeding plum for resistance against sharka dates from 1950s (Kegler et al. 1998, Hart- mann 1998) but so far the results are limited. The main goal of this study was to evaluate in the field the susceptibility to sharka of new plum cultivars obtained by conventional breeding.

\section{MATERIALS AND METHODS}

Plum trees of nine cultivars were planted in the experimental field located in Skierniewice, Łódź province, Poland, in April 2005. Before planting, the trees were tested by ELISA for the absence of Prunus necrotic ring spot virus (PNRSV) and Prune dwarf virus (PDV) - two ilarviruses transmitted with the pollen and able to cause leaf symptoms. The cultivars tested were: 'Katinka', 'Jubileum', 'Diana', 'Valjevka', 'Żółta Afaska' (the selection known in Poland under this name resembling the name of original Bulgarian myrobalan variety), 'Elena', 'Jojo', 'President', 'Vision' and 'Węgierka 
Zwykła' (Pozegaca type) - serving as reference, susceptible variety. Each cultivar was represented by 10 to 14 trees. Some of the planted trees declined and died soon after planting or in the next year. The lacking trees of 9 cultivars were re-planted in 2006. One more cultivar - 'Silvia', was also included originally in the trial, but declined trees of this cultivar were not re-planted and consequently, the data from few 'Silvia' trees left, were not taken into account in the final analysis. Plum trees naturally infected with Plum pox virus isolates belonging to strain D, dominating in Poland (Malinowski 2006), were present in the immediate vicinity of tested plants. Additionally, a number of trees was inoculated artificially to provide more infection sources. The results presented below refer only to plants, which were left for inoculation by aphids naturally occurring in the experimental field.

Observations of visual symptoms and ELISA tests of collected leaf samples were conducted once or twice a year during the summer. Most of DAS-ELISA tests were performed using polyclonal antibodies prepared in the Institute of Pomology and Floriculture (at present Institute of Horticulture). In 2011 the samples were additionally tested in parallel using commercially available monoclonal antibodies. The results, in terms of positive/negative classification, were the same in both tests.

Sharka-like symptoms were observed on some fruits of 'Jojo' cultivar. In order to verify the hypothesis of a viral origin of these symptoms, the following experiment was performed in 2008. Fifty seven individual fruits were cut in halves; stones and fruit flesh were checked for the sharka-like symptoms: red spots on the stone with fruit flesh hard to remove from stone and showing some discoloration (Fig. 1). Observations were recorded and samples of fruit flesh (with a small piece of fruit skin) were tested for the presence of Plum pox virus (PPV) using DAS-ELISA. To reduce a risk of bias the order of samples in ELISA was the same as the one used when checking for symptoms. That means that symptom negative and positive fruits were tested in the same random order.

After reading the plate, results were sorted out into two sets, corresponding to symptom posi- tive and symptom negative samples. Average value and standard deviation was calculated for each set. The significance of the difference between average values of $\mathrm{A}_{430-630}\left(\mathrm{~A}_{405}-\mathrm{A}_{630}\right)$ for two sets was verified using two-sided Student's t-test.

\section{RESULTS}

The first symptoms of sharka were observed on two 'Katinka' trees already in August 2005, demonstrating high infection pressure and high susceptibility of this cultivar. In 2008, only trees of two cultivars: 'Jojo' and 'Elena' remained free from PPV infection whereas at least one tree of all the other cultivars was PPV-positive, as confirmed by ELISA and leaf symptoms. The level of infection as observed in 2008 and 2012 is summarized for all cultivars in Table 1. Please, note that one tree of 'Vision' cv. and one tree of 'Elena' cv. got infected with PPV, but died before 2012. Those infections should be taken into account when evaluating the susceptibility of these cultivars during the entire experiment.

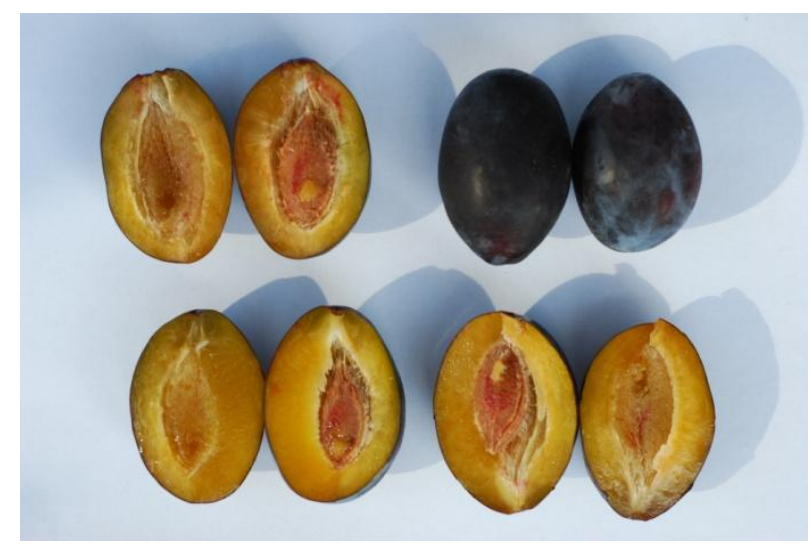

Fig. 1. Sharka-like symptoms on the fruits of 'Jojo' plum. These fruits tested negative in ELISA for the presence of Plum pox virus.

Many 'Jojo' fruits displayed sharka-like symptoms, especially on stones and fruit flesh. Out of 57 fruits randomly collected for the tests performed in 2008, 37 showed sharka-like symptoms (Fig. 1). For the remaining 20, stones were clean and flesh could be easily removed. All 'Jojo' fruits, regardless of sharka-like symptoms, tested negative for the presence of PPV in ELISA. 
Table 1. Susceptibility of plum cultivars to Plum pox virus (PPV). Different duration of exposure to infection for some plants reflects the fact that some of the trees planted originally in April 2005 had died during the first 2 years after planting, and were later replanted

\begin{tabular}{lccccc}
\hline \multirow{2}{*}{ Cultivar } & $\begin{array}{c}\text { Number of years } \\
\text { of exposure } \\
\text { to sharka }\end{array}$ & $\begin{array}{c}\text { PPV infected } \\
\text { in } 2008\end{array}$ & $\begin{array}{c}\text { PPV infected } \\
\text { in 2012 }\end{array}$ & $\begin{array}{c}\text { Non-infected with } \\
\text { PPV in 2012 }\end{array}$ & $\begin{array}{c}\text { Growing in the } \\
\text { field in 2012 }\end{array}$ \\
\hline Katinka & $7-8$ & 10 & 12 & 1 & 13 \\
Jubileum & $7-8$ & 1 & 6 & 5 & 11 \\
Diana & 8 & 2 & 3 & 8 & 11 \\
Valjevka & 8 & 1 & 2 & 9 & 11 \\
Żółta Afaska & $7-8$ & 3 & 6 & 6 & 12 \\
Elena & $7-8$ & 0 & $3(4)$ & 2 & 5 \\
Jojo & 8 & 0 & 0 & 11 & 11 \\
President & $7-8$ & 2 & 8 & 0 & 8 \\
Vision & $7-8$ & 1 & $2(3)$ & 9 & 11 \\
Węgierka Zwykła & 8 & 4 & 9 & 3 & 12 \\
\hline
\end{tabular}

${ }^{1}$ One 'Vision' tree, which was found infected in 2008 and one tree of 'Elena' cv., which was found infected with PPV in 2010 died before 2012. Numbers given in parenthesis refer to the total number of trees, which got infected, even if they did not survive till 2012

Average values of $\mathrm{A}_{430-630}\left(\mathrm{~A}_{405}-\mathrm{A}_{630}\right)$ for two sets (symptomatic and symptomless) were: $0.0900 \pm$ 0.0085 and $0.0884 \pm 0.0048$, and were not significantly different. $\mathrm{P}$ value of $\mathrm{t}$-Student statistics test was 0.37).

\section{DISCUSSION}

Small-scale evaluations of the reaction of newly introduced cultivars of fruit trees to dangerous pests or pathogens, like Plum pox virus, are very helpful in avoiding big losses in commercial fruit production. In general, several aspects of plant-pathogen interaction can be studied, first in the glasshouse, then in the field. Unfortunately, results obtained in different experiments are sometimes hard to interpret due to different definitions being sometimes used for same phenomenon, or even worse using the same word to refer to different ideas (Kegler et al. 1998). In the presented study, we evaluated the susceptibility of several plum cultivars to infection with Plum pox virus borne by aphids naturally occurring in the field. Tested plants were being grown for 7-8 years in the close vicinity of diseased trees serving as sources of infection with PPV-D isolates. According to our results 'Katinka' and 'President' showed very high susceptibility to sharka, whereas 'Val- jevka' and 'Vision' were moderately susceptible (20-30\% trees infected). Our results confirmed lack of susceptibility of 'Jojo' to PPV, when challenged with viruliferous aphids in the field, reported by Hartmann et al. (2004). There is no contradiction however, between our results and the results reported by Polák et al. (2005) suggesting, that transport of some PPV isolates may occur via 'Jojo' tissue to susceptible rootstocks. This question was not addressed in our experiment. According to the results obtained in this study, the symptoms often observed on fruit flesh and stones of 'Jojo', and resembling sharka damage, were not caused by PPV infection. No ELISA detectable amounts of the virus were detected in symptomatic fruits. The reason for this phenomenon remains unclear. Its occurrence, however, encourages the further breeding efforts, with the ultimate goal of producing new plum cultivars, sharka resistant or not susceptible to sharka, and showing improved production traits.

\section{Acknowledgements}

Many thanks are due to Mrs Grażyna Szczechowicz, for the excellent technical assistance.

\section{REFERENCES}

Cambra M, Capote N, Myrta A., Llácer G. 2006. Plum pox virus and the estimated costs associated with 
sharka disease. Bulletin OEPP/EPPO Bulletin 36: 202-204.

Hartmann W. 1998. Breeding of plums and prunes resistant to Plum pox virus. Acta Virol. 42: 230-232.

Hartmann W. 2004. 'Jojo' - the first absolutely resistant plum variety. $8^{\text {th }}$ International Symposium on Plum and Prune. Genetics, Breeding and Pomology, Lofthus, Norway. Book of Abstracts p. 84.

Kegler H., Fuchs E., Grüntzig M., Schwarz S. 1998. Some results of 50 years research on the resistance to Plum pox virus. Acta Virol. 42: 200-215.

Krczal H., Kunze L. 1976. Experiments on the transmissibility of sharka virus by aphids. Acta Hort. 67: 165-170.
Kunze L., Krczal H. 1971. Transmission od sharka virus by aphids. Annales de Phytopathologie, VIIIe Symposium européen sur les maladies a virus des arbres fruitiers, Bordeaux 24-30 Juin 1970, pp. 255-260.

Malinowski T. 2006. Plum pox virus (PPV) in Poland. EPPO Bulletin 36: 212-213. DOI: 10.1111/j.13652338.2006.00962.x.

Moreno A., Fereres A., Cambra M. 2009. Quantitative estimation of Plum pox virus targets acquired and transmitted by a single Myzus persicae. Arch. Virol. 154: 1391-1399.

Polák J., Pívalová J., Svoboda J. 2005. Prune cv. 'Jojo' resistance to different strains of Plum pox virus. Plant Protect. Sci. 41(2): 47-51. 